\title{
Host Specificity of DNA in Haemophilus influenzae: The Restriction and Modification Systems in Strains $\mathrm{R} b$ and $\mathrm{R} f$
}

\author{
By A. PIEKAROWICZ AND L. KAUC \\ Institute of Microbiology, University of Warsaw, Warsaw, Poland \\ AND S. W. GLOVER \\ Department of Genetics, University of Newcastle upon Tyne, \\ Newcastle upon Tyne, NEI ${ }_{7} R U$
}

(Received I7 September 1973)

\begin{abstract}
SUMMARY
Haemophilus influenzae $\mathrm{R} f$ possesses two distinct host specificity systems $\mathrm{FI}_{\mathrm{I}}$ and F2 each of which is able to restrict and modify Haemophilus phage HPI $c$, while strain $\mathrm{R} b$ possesses only one system, B. Among restriction-deficient mutants isolated from strain $\mathrm{R} f$, the $\mathrm{r}^{-} \mathrm{m}^{+}$as well as $\mathrm{r}^{-} \mathrm{m}^{-}$phenotypes for these two systems were obtained after either one or two mutational steps. The FI system was introduced into $H$. influenzae $\mathrm{R} d$ by genetic transformation to show that the DI and FI systems are not allelic.
\end{abstract}

\section{INTRODUCTION}

Many strains of bacteria can recognize DNA from other so-called foreign strains. One result of this recognition is that the foreign DNA molecule can be cleaved by strain specific restriction endonucleases that cut DNA, producing a limited number of fragments (Meselson \& Yuan, 1968; Linn \& Arber, 1968; Roulland-Dussoix \& Boyer, 1969; Smith \& Wilcox, I970). Protection against restriction is provided by another enzyme, modification methylase, that converts a very limited number of adenine or cytosine residues into 6-methylaminopurine and 5-methylcytosine respectively (Smith, Arber \& Kühnlein, 1972; Brockes, Brown \& Murray, 1972; Hattman, Gold \& Plotnik, 1972). In molecular terms a given DNA hostspecificity system can be defined by the sequence of base pairs recognized by the restriction endonuclease and modification methylase. The sequence of base-pairs recognized by restriction enzyme isolated from Haemophilus influenzae $\mathrm{R} d$ and by two $\mathrm{R}$ factor restriction enzymes have already been determined (Kelly \& Smith, I970; Hedgpeth, Goodman \& Boyer, 1972; Bigger, Murray \& Murray, 1973).

The restriction and modification properties of Haemophilus influenzae have been characterized in vitro (Smith \& Wilcox, 1970; Gromkova \& Goodgal, 1972; Gromkova, Bendler \& Goodgal, I973; P. Roy, personal communication) as well as in vivo (Glover \& Piekarowicz, 1972; Piekarowicz \& Glover, 1972). Piekarowicz \& Glover (1972) have shown that each of the serological types of $H$. influenzae carry different DNA restriction and modification systems. Moreover, strain Ra carries two genetically distinct host-specificity systems each of which is able to restrict Haemophilus phages HPIcI and S2.

In this paper we describe the isolation and characterization of restriction-deficient mutants for host specificities in Haemophilus influenzae $\mathrm{R} f$ and $\mathrm{R} b$. The accompanying paper is concerned with the similarity between $H$. influenzae $\mathrm{R} e$ and $\mathrm{R} f$ host-specificity systems. 
Table I. Strains of Haemophilus influenzae

Strain designation
H. influenzae $\mathrm{R} d 30$
H. influenzae $\mathrm{R} d \mathrm{I} 23$
H. influenzae $\mathrm{R} d 44 \mathrm{I}$
H. influenzae $\mathrm{R} f$
H. influenzae $\mathrm{R} f$
H. influenzae $\mathrm{R} d 44 \mathrm{I}-\mathrm{I}$
H. influenzae $\mathrm{R} e$
H. influenzae $\mathrm{R} b$

Characteristics

Streptomycin resistant

Streptomycin resistant

Streptomycin resistant

Wild-type

Novobiocin resistant

Streptomycin resistant

HPI c I lysogen

Wild-type

Wild-type
Source

-

$-$

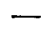

Dr G. Leidy

Obtained in

this laboratory

Obtained in

this laboratory

Dr G. Leidy

Dr G. Leidy
Reference

Glover \&

Piekarowicz (I972)

Glover \&

Piekarowicz (1972)

Glover \&

Piekarowicz (1972)

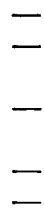

\section{METHODS}

Bacterial strains. The strains of Haemophilus influenzae used are listed in Table $\mathrm{I}$. Bacterial cultures were routinely stored at $-45^{\circ} \mathrm{C}$ in supplemented BHI medium (see Media) containing $15 \%(\mathrm{v} / \mathrm{v})$ glycerol. For each experiment samples were thawed, diluted in fresh medium and cultures grown at $37^{\circ} \mathrm{C}$ on a shaker until they reached titres of $5 \times 10^{8}$ to $\mathrm{I} \times 10^{9}$ bacteria $/ \mathrm{ml}$.

Bacteriophages. The phage HPI $c$ I was originally isolated by Harm \& Rupert (I963). Phage S2 was isolated by Bendler \& Goodgal (1968). These phages were kindly supplied by R. M. Herriott and J. W. Bendler respectively.

Media. Supplemented BHI was $3.7 \%$ (w/v) Brain Heart Infusion (BHI) (Difco) supplemented with $10 \mu \mathrm{g}$ haemin $/ \mathrm{ml}$ plus $2 \mu \mathrm{g}$ NAD $/ \mathrm{ml}$. Other media and salt solutions were as described elsewhere (Piekarowicz \& Glover, 1972; Spencer \& Herriott, 1965).

Phage techniques. The general techniques were as described by Adams (1959) and special techniques relating to HPI $c$ I phage are those described by Harm \& Rupert (I963) and for phage $\mathrm{S}_{2}$ as described by Bendler \& Goodgal (I968).

Mutagenesis. Bacteria were mutagenized with $N$-methyl- $N$-nitroso- $N$-nitroguanidine according to the procedure of Piekarowicz \& Glover (1972).

Isolation of restriction-deficient mutants. For the isolation of mutants, samples of mutagenized bacteria were thawed and plated at appropriate dilution on supplemented BHI medium and incubated at $37^{\circ} \mathrm{C}$. Colonies were then picked into I $\mathrm{ml}$ supplemented $\mathrm{BHI}$ medium and incubated for $16 \mathrm{~h}$ at $37^{\circ} \mathrm{C}$ without aeration. Each culture was then used in a qualitative test for restriction and modification.

Spot test for restriction and modification. These methods were in general as described previously (Piekarowicz \& Glover, 1972).

Quantitative test for restriction and modification. Restriction and modification were accurately assayed by determining the efficiency of plating (e.o.p.) of phage stocks on appropriate strains. Routinely the phages were diluted and mixed with $2 \times 10^{8}$ bacteria $/ \mathrm{ml}$ of the indicator strain in $2.5 \mathrm{ml}$ soft $\mathrm{BHI}$ agar containing $\mathrm{CaCl}_{2}$ (0.00I M) at 43 to $45^{\circ} \mathrm{C}$ and poured over Io to $15 \mathrm{ml}$ of supplemented $\mathrm{BHI}$ agar also containing $0.00 \mathrm{I} \mathrm{M}-\mathrm{CaCl}_{2}$. Plaques were counted after 16 to $24 \mathrm{~h}$ incubation at $37^{\circ} \mathrm{C}$.

One-cycle phage infection. These techniques were reported earlier (Piekarowicz \& Glover, 1972).

Isolation of DNA. DNA was isolated and purified by the method of Marmur (I96I) except that the final step of precipitation with isopropanol was omitted. 
Table 2. Efficiency of plating of phages $H P_{1} c \mathrm{r}$ and $S_{2}$ on strains of Haemophilus influenzae

\begin{tabular}{|c|c|c|c|}
\hline $\begin{array}{l}\text { Phage grown on } \\
\text { Haemophilus influenzae strains }\end{array}$ & $\mathrm{R} f$ & $\mathrm{R} d 30$ & $\mathrm{R} d \mathrm{I}_{123}$ \\
\hline $\operatorname{HPI} c \mathrm{I} . \mathrm{R} d_{30} *$ & $I \times 10^{-9}$ & I & $1 \times 10^{-3}$ \\
\hline HPIcI.RdI $23 \dagger$ & $\mathrm{I} \times \mathrm{IO}^{-9}$ & I & I \\
\hline HPI $c$ I . Rf & I & $1 \times 10^{-1}$ & $1 \times 10^{-3}$ \\
\hline $\mathrm{S}_{2} \cdot \mathbf{R} d_{30}$ & $1 \times 10^{-9}$ & I & $1 \times 10^{-3}$ \\
\hline
\end{tabular}

Competence. The preparation of competent Haemophilus influenzae $\mathrm{R} d$ cultures was based on the method of Spencer \&\& Herriott (I965). The sample of supplemented BHI culture $\left(5 \times 10^{8}\right.$ cells $\left./ \mathrm{ml}\right)$ was centrifuged and washed once with M-II medium and then resuspended in the same volume of M-IV medium. Competence was allowed to develop for $90 \mathrm{~min}$ at $37^{\circ} \mathrm{C}$.

Transformation. The general transformation techniques were essentially those of Goodgal \& Herriott (196I). A $0.1 \mathrm{ml}$ sample of DNA isolated from a Haemophilus influenzae $\mathrm{R} f$ novobiocin-resistant strain of $0 . \mathrm{I} \mathrm{ml}$ of competent strain Rd44I (HPIcI) were mixed in $2.8 \mathrm{ml}$ of $\mathrm{BHI}$ and incubated for $120 \mathrm{~min}$ at $37^{\circ} \mathrm{C}$. The transformed cells were poured directly onto BHI medium containing $2.5 \mu \mathrm{g}$ novobiocin $/ \mathrm{ml}$ and incubated $24 \mathrm{~h}$ at $37^{\circ} \mathrm{C}$ to give colonies of transformants.

Isolation of Haemophilus influenzae $\mathrm{R} d$ strain with an $\mathrm{R} f$ host specificity system. To eliminate non-competent cells from the screening procedure (Michalka \& Goodgal, I969), a sample of $0 . \mathrm{I} \mathrm{ml} \mathrm{DNA} \mathrm{(I} \mu \mathrm{g}$ ) from $H$. influenzae $\mathrm{R} f$ resistant to $2.5 \mu \mathrm{g}$ novobiocin $/ \mathrm{ml}$ and $0 . \mathrm{I} \mathrm{ml}$ DNA ( $\mathrm{I} 0 \mu \mathrm{g}$ ) from wild-type $H$. influenzae $\mathrm{R} f$ were mixed with $0 . \mathrm{I} \mathrm{ml}$ of competent strain $\mathrm{R} d 44 \mathrm{I}$ (HPICI) in $2.8 \mathrm{ml} \mathrm{BHI}$ and incubated for $120 \mathrm{~min}$. The transformants were poured directly into $2.5 \mathrm{ml}$ soft agar on the surface of $10 \mathrm{ml}$ hard agar containing $2.5 \mu \mathrm{g}$ novobiocin $/ \mathrm{ml}$ and the plates were incubated overnight at $37^{\circ} \mathrm{C}$ to give small colonies. To detect clones transformed to donor type (Rf) host specificity the colonies were overlayed with the following indicator strains: $H$. influenzae $\mathrm{R} f$ wild-type, $\mathrm{R} f 232$ and $\mathrm{R} f \mathrm{IOI}$ in soft agar. Colonies spontaneously releasing HPIcI phage with modification specific for $H$. influenzae $\mathrm{R} f$ formed haloes of lysed cells in the top layer containing the appropriate indicator bacteria. They were stabbed and streaked on antibiotic-containing agar to eliminate sensitive indicator bacteria. Single colonies were grown for further examination and frozen in broth containing $15 \%(\mathrm{v} / \mathrm{v})$ glycerol.

\section{RESULTS}

Analysis of restriction and modification properties of Haemophilus influenzae $\mathrm{R} f$

Piekarowicz \& Glover (1972) showed that unmodified phage HPIcI.O is restricted by Haemophilus influenzae $\mathrm{R} f$ with a very high efficiency (e.o.p. about $10^{-9}$ ). To ensure that the observed low e.o.p. of phage HPI $c \mathrm{I}$ on strain $\mathrm{R} f$ was due to restriction and modification, two experiments were carried out. In the first experiment we checked the low efficiency of plating of phage HPrcr.O by measuring restriction in supplemented BHI cultures. A sample of $5 \times 10^{9} \mathrm{H}$. influenzae $\mathrm{Rf} / \mathrm{ml}$ was infected with $\mathrm{HPI} \mathrm{cr} . \mathrm{O}$ phage at a multiplicity of infection of 2.0 and after 15 min for adsorption a large number of samples were plated on $H$. influenzae $\mathrm{R} f$ as an indicator strain. This procedure almost completely eliminated plaques arising from unadsorbed phage but still allowed the permissive fraction 


\section{Table 3. One-cycle infection of Haemophilus influenzae $\mathrm{R} d$ with phage HPIcr. $\mathrm{Rf}$}

$\begin{array}{lc}\text { No. bacteria/ml } & 8 \times 10^{9} \\ \text { No. phages/ml } & 1 \cdot 3 \times 10^{9} \\ \text { Multiplicity of infection } & 0.16 \\ \text { Adsorption } & 99 \% \\ \begin{array}{l}\text { No. infective centres on: } \\ \quad \mathrm{R} d 30\end{array} & \\ \mathrm{R} f & 2.5 \times 10^{8} \\ \quad \begin{array}{l}\text { Transmission coefficient } \\ \text { Progeny phage on: }\end{array} & \mathrm{I} \cdot 2 \times 10^{8} \\ \quad \mathrm{R} d 3 \mathrm{O} & 2 \times 10^{-1} \\ \mathrm{R} f & \\ \begin{array}{l}\text { Average burst size } \\ \text { Percentage of progeny phage } \\ \text { which plate on } \mathrm{R} f\end{array} & 1 \cdot 3 \times 10^{10} \\ \end{array}$

of infected bacteria to yield plaques. The results in Table 2 confirmed our previous observations on the very high efficiency of restriction of $\mathrm{HPI} c \mathrm{I}$ and $\mathrm{S}_{2}$ phages in $H$. influenzae strain $\mathrm{R} f$.

In the second experiment, one-cycle phage infection was carried out using phage HPI $c \mathrm{I}$. R $f$ to infect an $\mathrm{r}^{-} \mathrm{m}^{-}$strain of $H$. influenzae $\mathrm{R} d$. Phage HPIcr. $\mathrm{R} f$ can infect the $\mathrm{r}^{-} \mathrm{m}^{-}$strain efficiently and a major part of the progeny phage is unable to form plaques on the restricting indicator strain $\mathrm{R} f$, indicating that the ability to form plaques on $\mathrm{R} f$ is not heritable (Table 3).

\section{Isolation of restriction-deficient mutants of Haemophilus influenzae $\mathrm{R} f$}

Piekarowicz \& Glover (1972) showed that the low e.o.p. of phage HPIcI.O on Haemophilus influenzae $\mathrm{R} a$ (about $\mathrm{I0}^{-6}$ ) is due to the activity of two systems, $\mathrm{Ar}$ and $\mathrm{A} 2$, which reduce the e.o.p. to $3 \times 10^{-9}$ and $5 \times 10^{-3}$ respectively. Haemophilus influenzae $\mathrm{R} d$ possesses only one detectable host specificity system (Glover \& Piekarowicz, 1972) which reduces the e.o.p. to $\mathrm{I} \times 10^{-3}$. In the light of these results the very low e.o.p. of HPICI.O on $\mathrm{R} f$ strain makes it likely that this strain has two or more host-specificity systems.

The restriction-deficient mutants of Haemophilus influenzae $\mathrm{R} f$ were isolated following NTG mutagenesis as described in Methods. In Expt I (Table 4) a total of 8 mutants was isolated from about 250 colonies and in Expt II a total of 14 mutants was isolated from about 300 colonies. None of the restriction-deficient mutants isolated is completely permissive for phage HPI $c$ I.O. The great majority of them (20 out of 22 ) are able to hostmodify phage HPI $c \mathrm{I}$ so that it can plaque on strain $\mathrm{R} f$ with an efficiency of $\mathrm{I} \cdot 0$, but the other two cannot. None of them is fully $\mathrm{m}^{-}$, since phage from these two mutants plaques at higher efficiency on $\mathrm{R} f$ than does HPIcI.O. The mutants have thus either an $\mathrm{r}^{ \pm} \mathrm{m}^{+}$or an $\mathrm{r}^{ \pm} \mathrm{m}^{ \pm}$ phenotype. One obvious explanation of these results would be that strain $\mathrm{R} f$ possesses more than one genetically independent system of restriction and modification.

\section{Two restriction and modification systems in Haemophilus influenzae $\mathbf{R} f$}

To test the possibility that Haemophilus influenzae $\mathrm{R} f$, like strain $\mathrm{R} a$, possesses more than one restriction and modification system, phage HPI $c$ I was grown on each of the mutants and its e.o.p. on each of the other mutants was measured (Table 5). The simplest explanation 
Table 4. Restriction and modification properties of restriction-deficient mutants of Haemophilus influenzae $\mathrm{R} f$

\begin{tabular}{|c|c|c|c|}
\hline Expt no. & Mutant no. & $\begin{array}{l}\text { Restriction } \\
\text { e.o.p. of HPIcI. O* } \\
\text { on mutant }\end{array}$ & $\begin{array}{r}\text { Modificatic } \\
\text { e.o.p. of progen } \\
\text { HPIcI mutant }\end{array}$ \\
\hline \multirow[t]{8}{*}{ I } & IOI & $2 \times 10^{-4}$ & $2 \times 10^{-6}$ \\
\hline & 102 & $4 \times 10^{-4}$ & I \\
\hline & 103 & $5 \times 10^{-7}$ & I \\
\hline & 104 & $\mathrm{I} \times 10^{-6}$ & I \\
\hline & 106 & $\mathrm{I} \times 10^{-7}$ & I \\
\hline & 109 & $1 \times 10^{-7}$ & I \\
\hline & II I & $5 \times 10^{-7}$ & I \\
\hline & II 3 & $2 \times 10^{-7}$ & I \\
\hline \multirow[t]{13}{*}{ II } & 214 & $1 \times 10^{-7}$ & I \\
\hline & 215 & $1 \times 10^{-7}$ & I \\
\hline & 217 & $1 \times 10^{-6}$ & I \\
\hline & 218 & $1 \times 10^{-7}$ & I \\
\hline & 220 & $1 \times 10^{-3}$ & I \\
\hline & $22 \mathrm{I}$ & $1 \times 10^{-7}$ & I \\
\hline & 222 & $2 \times 10^{-6}$ & I \\
\hline & 225 & $1 \times 10^{-7}$ & I \\
\hline & 227 & $1 \times 10^{-3}$ & I \\
\hline & 229 & $\mathfrak{I} \times 10^{-5}$ & I \\
\hline & 230 & $1 \times 10^{-7}$ & I \\
\hline & 231 & $1 \times 10^{-7}$ & I \\
\hline & 232 & $1 \times 10^{-6}$ & $2 \times 10^{-3}$ \\
\hline
\end{tabular}

The mutants were isolated after NTG treatment as described in Methods.

Expt I: NTG $300 \mu \mathrm{g} / \mathrm{ml}$, treatment for $30 \mathrm{~min}$ at $37^{\circ} \mathrm{C}, 0 . \mathrm{I} \%$ survivors.

Expt II: NTG $300 \mu \mathrm{g} / \mathrm{ml}$, treatment for $30 \mathrm{~min}$ at $37^{\circ} \mathrm{C}, 0.06 \%$ survivors.

* HPıc1.O was phage grown on H. influenzae $\mathrm{Rd} 30$ (Glover \& Piekarowicz, 1972).

$\dagger$ The e.o.p. of progeny phage HPIcI mutant on all mutants was I.

Table 5. Efficiency of plating on restriction-deficient mutants of Haemophilus influenzae $\mathrm{R} f$ of phage $H P \mathrm{I} c \mathrm{I}$ previously grown on the mutants

Host

strain

RfIOI

$\mathrm{R} f \mathrm{IO} 2$

Rf 103

Rf 104

$\mathrm{R} f_{\mathrm{IO}} \mathrm{6}$

Rf I I I

$\mathrm{R} f 217$

$\mathrm{R} f 220$

$\mathrm{R} f 222$

$\mathrm{R} f 227$

$\mathrm{R} f 229$

Rf 232

Rfw.t.

Previous host for phage HPIcI

$\begin{array}{lccc}\text { HPI } c \text { I.RfIOI } & \text { HPI } c \mathrm{I} . \mathrm{R} f 102 & \mathrm{HPI} c \mathrm{I} . \mathrm{R} f 232 & \mathrm{HPI} c \mathrm{I} \cdot \mathrm{R} f 217 \\ \mathrm{I} & \mathrm{I} & \mathrm{I} \times 10^{-4} & \mathrm{I} \\ \mathrm{I} & \mathrm{I} & \mathrm{I} \times 10^{-4} & \mathrm{I} \\ \mathrm{I} \times 10^{-7} & \mathrm{I} & 3 \times 10^{-4} & \mathrm{I} \\ 3 \times 10^{-5} & \mathrm{I} & 3 \times 10^{-3} & \mathrm{I} \\ 3 \times 10^{-5} & \mathrm{I} & 3 \times 10^{-3} & \mathrm{I} \\ 3 \times 10^{-5} & \mathrm{I} & 3 \times 10^{-3} & \mathrm{I} \\ \mathrm{I} \times 10^{-6} & \mathrm{I} & \mathrm{I} & \mathrm{I} \\ \mathrm{I} & \mathrm{I} & 3 \times 10^{-3} & \mathrm{I} \\ \mathrm{I} & \mathrm{I} & 3 \times 10^{-3} & \mathrm{I} \\ \mathrm{I} & \mathrm{I} & 3 \times 10^{-3} & \mathrm{I} \\ \mathrm{I} \times 10^{-7} & \mathrm{I} & 2 \times 10^{-3} & \mathrm{I} \\ \mathrm{I} \times 10^{-6} & \mathrm{I} & \mathrm{I} & \mathrm{I} \\ \mathrm{I} \times 10^{-6} & \mathrm{I} & 3 \times 10^{-3} & \mathrm{I}\end{array}$

Host specificity phenotype

$\mathrm{r}_{\mathrm{F} 1}^{-} \mathrm{m}_{\mathrm{F} 1}^{-} \mathrm{r}_{\mathrm{F} 2}^{+} \mathrm{m}_{\mathrm{F} 2}^{+}$

$\mathrm{r}_{\mathrm{F} 1}^{-} \mathrm{m}_{\mathrm{F} 1}^{+} \mathrm{r}_{\mathrm{F} 2}^{+} \mathrm{m}_{\mathrm{F} 2}^{+}$

$\mathrm{r}_{\mathrm{F} 1}^{ \pm} \mathrm{m}_{\mathrm{F} 1}^{+} \mathrm{r}_{\mathrm{F} 2}^{+} \mathrm{m}_{\mathrm{F} 2}^{+}$

$\mathrm{r}_{\mathrm{F} 1}^{ \pm} \mathrm{m}_{\mathrm{F} 1}^{+} \mathrm{r}_{\mathrm{F} 2}^{+} \mathrm{m}_{\mathrm{F} 2}^{+}$

$\mathrm{r}_{\mathrm{F} 1}^{ \pm} \mathrm{m}_{\mathrm{F} 1}^{+} \mathrm{r}_{\mathrm{F} 2}^{+} \mathrm{m}_{\mathrm{F} 2}^{+}$

$\mathrm{r}_{\mathrm{F} 1}^{+} \mathrm{m}_{\mathrm{F} 1}^{+} \mathrm{r}_{\mathrm{F} 2}^{+} \mathrm{m}_{\mathrm{F} 2}^{+}$

$\mathrm{r}_{\mathrm{F} 1}^{+} \mathrm{m}_{\mathrm{F} 1}^{+} \mathrm{r}_{\mathrm{F} 2} \mathrm{~m}_{\mathrm{F} 2}^{+}$

$\mathrm{r}_{\mathrm{F} 1}^{-} \mathrm{m}_{\mathrm{F} 1}^{+} \mathrm{r}_{\mathrm{F} 2}^{+} \mathrm{m}_{\mathrm{F} 2}^{+}$

$\mathrm{r}_{\mathrm{F} 1}^{+} \mathrm{m}_{\mathrm{F} 1}^{+} \mathrm{r}_{\mathrm{F} 2}^{+} \mathrm{m}_{\mathrm{F} 2}^{+}$

$\mathrm{r}_{\mathrm{F} 1}^{-} \mathrm{m}_{\mathrm{F} 1}^{+} \mathrm{r}_{\mathrm{F} 2}^{+} \mathrm{m}_{\mathrm{F} 2}^{+}$

$\mathrm{r}_{\mathrm{F} 1}^{ \pm} \mathrm{m}_{\mathrm{F} 1}^{+} \mathrm{r}_{\mathrm{F} 2}^{+} \mathrm{m}_{\mathrm{F} 2}^{+}$

$\mathrm{r}_{\mathrm{F} 1}^{+} \mathrm{m}_{\mathrm{F} 1}^{+} \mathrm{r}_{\mathrm{F} 2}^{-} \mathrm{m}_{\mathrm{F} 2}^{-}$

$\mathrm{r}_{\mathrm{F} 1}^{+} \mathrm{m}_{\mathrm{F} 1}^{+} \mathrm{r}_{\mathrm{F} 2}^{+} \mathrm{m}_{\mathrm{F} 2}^{+}$ 
Table 6. Double restriction-deficient mutants isolated from

Haemophilus influenzae $\mathbf{R} \mathbf{2 3 2}$

Cultures of $H$. influenzae $\mathrm{Rf} 232$ were treated with a final concentration of $300 \mu \mathrm{g} \mathrm{NTG} / \mathrm{ml}$ for $30 \mathrm{~min}$ at $37^{\circ} \mathrm{C}$ to give a survival of $0.01 \%$, as described in Methods. A total of 350 colonies was screened for restriction-deficient mutants with phage HPI $c$ I.O.

Previous host for phage HPIcI

HPIc1.Rf232-I05 HPI $c$ I. O*
Efficiency of plating on Haemophitus influenzae $\mathrm{R} f$ mutants

$\begin{array}{cccc}\mathrm{R} f 232-105 & \mathrm{R} f & \mathrm{R} f 232 & \mathrm{R} f \mathrm{IOI} \\ \mathrm{I} & \mathrm{I} \times 10^{-9} & \mathrm{I} \times 10^{-6} & 5 \times 10^{-3} \\ \mathrm{I} & \mathrm{I} \times 10^{-9} & \mathrm{I} \times 10^{-6} & \mathrm{I} \times \mathrm{IO}^{-4}\end{array}$

* Phage HPI $c$ I previously grown on strain Rd30 (Glover \& Piekarowicz, I972).

Table 7. Double restriction-deficient mutants isolated from

Haemophilus influenzae $\mathrm{R} f \mathrm{IOI}$

A culture of Haemophilus influenzae $\mathrm{R} f \mathrm{IOI}$ was treated with a final concentration of $300 \mu \mathrm{g} \mathrm{NTG} / \mathrm{ml}$ for $30 \mathrm{~min}$ at $37^{\circ} \mathrm{C}$ to give a survival of $0.01 \%$, as described in Methods. A total of 250 colonies was screened for restriction-deficient mutants with phage $\mathrm{HPI} c \mathbf{I}$.O.

\begin{tabular}{|c|c|c|c|}
\hline Mutant no. & $\begin{array}{l}\text { Restriction } \\
\text { e.o.p. of HPI } c \mathbf{I} . \mathrm{O}^{*} \\
\text { on mutants }\end{array}$ & $\begin{array}{l}\text { Modification } \\
\text { e.o.p. of progeny phage } \\
\text { HPIcI. mutant on } \mathrm{R} f \mathrm{IOI} \dagger\end{array}$ & $\begin{array}{l}\text { Phenotypes of } \\
\text { mutants deduced }\end{array}$ \\
\hline$R f$ IOI -8 & $1 \times 10^{-1}$ & I & $\mathrm{r}^{ \pm} \mathrm{m}^{+}$ \\
\hline $\mathrm{R} f_{\mathrm{IOI}-22}$ & I & $4 \times 10^{-2}$ & $\mathrm{r}^{-} \mathrm{m}^{ \pm}$ \\
\hline$R f_{I O I-26}$ & $\mathrm{I} \times 1 \mathrm{I}^{-1}$ & I & $\mathrm{r}^{ \pm} \mathrm{m}^{+}$ \\
\hline $\mathrm{R} f \mathrm{IOI}-82$ & I & $1 \times 10^{-4}$ & $\mathrm{r}^{-} \mathrm{m}^{-}$ \\
\hline RfIOI-I I 7 & I & I & $\mathrm{r}^{-} \mathrm{m}^{+}$ \\
\hline
\end{tabular}

* Phage previously grown on strain Rd30 (Glover \& Piekarowicz, 1972).

$\dagger$ The e.o.p. on all mutants was $\mathbf{I}$.

of these data is that mutants $\mathrm{R} f 232$ and $\mathrm{R} f$ Iol possess independent restriction and modification systems each one representing one of the two systems which are present in the wildtype $H$. influenzae $\mathrm{R} f$. We shall denote these systems FI and $\mathrm{F}_{2}$ so that the phenotype of $\mathrm{R} f 232$ can be written $\mathrm{r}_{\mathrm{F} 1}^{+} \mathrm{m}_{\mathrm{F} 1}^{+} \mathrm{r}_{\mathrm{F} 2}^{-} \mathrm{m}_{\mathrm{F} 2}^{-}$and the phenotype of $\mathrm{R} f \mathrm{IOI}$ can be written $\mathrm{r}_{\mathrm{F} 1}^{-} \mathrm{m}_{\mathrm{F} 1}^{-} \mathrm{r}_{\mathrm{F} 2}^{+} \mathrm{m}_{\mathrm{F} 2}^{+}$. The phenotypes of the other mutants can be deduced from whether they restrict phage grown on $\mathrm{R} f 232$ (i.e. HPI $c \mathrm{I}$.FI, O) in which case they are $\mathrm{r}_{\mathrm{F} 2}^{+}$or whether they restrict HPI $c \mathrm{I} . \mathrm{O}$, F2 (i.e. phage grown on $\mathrm{R} f \mathrm{IOI}$ ) in which case they are $\mathrm{r}_{\mathrm{F} 1}^{+}$. It is clear from the results presented in Table 5 that for both systems many of the mutants expressed phenotypes intermediate between + and - for restriction and also for modification. Most of them are characterized by changes in the FI system, perhaps because the screening procedure favours the isolation of this class of mutants. The e.o.p. of phage HPI $c \mathrm{I}$. O on $\mathrm{r}_{\mathrm{F} 1}^{+}$strains is about $\mathrm{I} \times 10^{-6}$ while the e.o.p. of phage $\mathrm{HPI} c \mathrm{I}$. O on $\mathrm{r}_{\mathrm{F} 2}^{+}$strains is much higher, about $2 \times 10^{-3}$.

\section{Double mutants isolated for restriction-deficiency from Haemophilus influenzae $\mathrm{R} f$}

The hypothesis that Haemophilus influenzae $\mathrm{R} f$ possesses two genetically distinct systems of restriction and modification was tested following the isolation of double restrictiondeficient mutants from $\mathrm{R} f 232$ and $\mathrm{R} f$ ror strains. If this hypothesis is correct, then it should be possible to isolate mutants with different phenotypes for these two systems and certain classes of mutants would be expected to occur only as a result of two mutations.

The $R f 232$ and $R f$ IOI strains were treated with NTG and the survivors cloned and screened 
Table 8. One-cycle phage infection on Haemophilus influenzae $\mathrm{R} f \mathrm{IOI}$

Growth of phage HPIcr. $R f_{232}$ in strain $\mathrm{R} f \mathrm{IOI}$.

$\begin{array}{lc}\text { No. bacteria/ml } & 8 \times 10^{8} \\ \text { No. phages/ml } & 7 \times 10^{6} \\ \text { Multiplicity of infection } & 0 \cdot 0 \mathrm{I} \\ \text { Adsorption } & 99 \% \\ \text { No. infective centres on: } & \\ \text { R } f \text { IOI } & \mathrm{I} \cdot 5 \times 10^{4} \\ \text { R } f 232 & \mathrm{I} \cdot 0 \times 10^{4} \\ \text { R } f & 6 \cdot 0 \times 10^{3} \\ \text { Transmission coefficient } & 2 \times 10^{-3} \\ \text { Progeny phage plated on: } & \\ \text { R } f \text { IoI } & \mathrm{I} \cdot 4 \times 10^{6} \\ \text { R } f 232 & \mathrm{I} \cdot 4 \times 10^{4} \\ \text { R } f & \mathrm{I} \cdot 2 \times 10^{4} \\ \text { Average burst size } & 95 \\ \text { Percentage of progeny phage which plate on: } & \\ \text { R } f 10 \mathrm{I} & 100 \\ \text { R } f 232 & \mathrm{I} \\ \text { R } f & 0.9\end{array}$

for restriction-deficient mutants. Several double mutants were obtained and their restriction and modification properties are summarized in Tables 6 and 7. Only one mutant which was completely restriction-deficient was obtained from strain $\mathrm{R} f 232$. This mutant accepts phage $\mathrm{HPI} c \mathrm{I} . \mathrm{O}$ at an e.o.p. of $\mathrm{r} \cdot \mathrm{O}$ and the phage propagated on this strain totally lacks $\mathrm{R} f$ modification. The phenotype of this double mutant is therefore $r_{\mathrm{F} 1}^{-} m_{\overline{F 1}}^{-} r_{\mathrm{F} 2}^{-} m_{\mathrm{F} 2}^{-}$. Three completely restriction-deficient double mutants were obtained after mutagenesis of strain $\mathrm{R} f \mathrm{IOI}$. However, they differ in modification. One of them, $\mathrm{R} f \mathrm{IOI}-82$, is completely modification deficient, another, RfIOI-II7, has the same modification properties as the parental strain $\mathrm{R} f \mathrm{IOI}$, while the third, $\mathrm{R} f \mathrm{IOI}-22$, is intermediate. The phenotypes of these double mutants are therefore $\mathrm{r}_{\mathrm{F} 1}^{-} \mathrm{m}_{\mathrm{F} 1}^{-} \mathrm{r}_{\mathrm{F} 2}^{-} \mathrm{m}_{\mathrm{F} 2}^{-}\left(\mathrm{R} f_{\mathrm{IOI}}-82\right), \mathrm{r}_{\mathrm{F} 1}^{-} \mathrm{m}_{\mathrm{F} 1}^{-} \mathrm{r}_{\mathrm{F} 2}^{-} \mathrm{m}_{\mathrm{F} 2}^{+}\left(\mathrm{R} f_{\mathrm{IOI}-\mathrm{II} 7}\right)$ and $\mathrm{r}_{\mathrm{F} 1}^{-} \mathrm{m}_{\mathrm{F} 1}^{-} \mathrm{r}_{\mathrm{F} 2}^{-} \mathrm{m}_{\mathrm{F} 2}^{+}$ (RfIOI-22). Mutants with the phenotype $\mathrm{r}_{\mathrm{F} 2}^{+} \mathrm{m}_{\mathrm{F} 2}^{+}$were also isolated (see Table 7).

The properties of double mutants isolated for their restriction-deficiency from one-step mutants $\mathrm{R} f 232$ and $\mathrm{R} f$ ror confirm the hypothesis that Haemophilus influenzae $\mathrm{R} f$ possesses two separate host-specificity systems. For each host specificity system the phenotypes $\mathrm{r}^{-} \mathrm{m}^{+}$and $\mathrm{r}^{-} \mathrm{m}^{-}$were obtained in approximately equal numbers. All of the $\mathrm{R} f$ one-step mutants which were obtained were mutated in one or other host specificity but not in both. Strains defective in both systems were obtained only as a result of two mutational events. Like the host-specificity systems in strain Ra (Piekarowicz \& Glover, 1972) and unlike the host-specificity system in strain $R d$ (Glover \& Piekarowicz, 1972) the two host-specificity systems FI and F2 are stable and the mutants do not revert at high frequency.

One cycle phage infection experiments with $\mathrm{R} f$ host specificity systems $F_{\mathrm{I}}$ and $F_{2}$

The restriction and modification properties of two host-specificity systems FI and F2 in Haemophilus influenzae $\mathrm{R} f$ were examined in a series of one-cycle phage infection experiments. There was no difference in adsorption or burst size for fully modified phage HPIcI.Rf 
Table 9. Efficiency of plating of phage $H P \mathrm{I} c \mathrm{I} . R d_{44 \mathrm{I}-T F_{\mathrm{I}}}$ on strains of Haemophilus influenzae

\begin{tabular}{ll}
\multicolumn{1}{c}{ Strain } & E.o.p. of $\mathrm{HPI} c \mathrm{I} \cdot \mathrm{R} d 44 \mathrm{I}-\mathrm{TFI}$ \\
$\mathrm{R} f$ wild-type & $\mathrm{I} \times \mathrm{IO}^{-3}$ \\
$\mathrm{R} f 232\left(\mathrm{r}_{\mathrm{F} 1}^{+} \mathrm{m}_{\mathrm{F} 1}^{+} \mathrm{r}_{\mathrm{F} 2}^{-} \mathrm{m}_{\mathrm{F} 2}^{-}\right)$ & $\mathrm{I}$ \\
$\mathrm{R} f \mathrm{I}$ I I $\left(\mathrm{r}_{\mathrm{F} 1}^{-} \mathrm{m}_{\mathrm{F} 1}^{-} \mathrm{r}_{\mathrm{F} 2}^{+} \mathrm{m}_{\mathrm{F} 2}^{+}\right)$ & $\mathrm{I} \times \mathrm{IO}^{-3}$ \\
$\mathrm{R} d \mathrm{I} 23\left(\mathrm{r}_{\mathrm{D} 1}^{+} \mathrm{m}_{\mathrm{D} 1}^{+}\right)$ & $\mathrm{I}$ \\
$\mathrm{R} d 44 \mathrm{I}\left(\mathrm{r}_{\overline{\mathrm{D} 1}}^{-} \mathrm{m}_{\mathrm{D} 1}^{+}\right)$ & $\mathrm{I}$
\end{tabular}

between the wild-type strain $\mathrm{R} f$ and the mutants $\mathrm{R} f 232$ and $\mathrm{R} f \mathrm{IOI}$ which possess only the $F_{I}$ and F2 systems respectively. The transmission coefficient (i.e. the fraction of infected bacteria which produce progeny phage) for HPIcI.O in $\mathrm{R}_{232} \mathrm{r}_{\mathrm{F} 1}^{+}$is approximately $10^{-6}$ and the transmission coefficient for phage HPI $c \mathrm{I}$.O in $\mathrm{RfIOI} \mathrm{r}_{\mathrm{F}_{2}}^{+}$is approximately $\mathrm{IO}^{-3}$. Together, these account entirely for the efficiency of plating of HPIcI.O on strain $\mathrm{R} f$ $\mathrm{r}_{\mathrm{F} 1}^{+}, \mathrm{r}_{\mathrm{F} 2}^{+}$.

Interesting confirmation of previous results was obtained in the one-cycle infection experiments with phage $\mathrm{HPI} c \mathrm{I}$.FI in strain $\mathrm{R} f \mathrm{IOI} \mathrm{r}_{\mathrm{F} 1}^{-} \mathrm{m}_{\mathrm{F} 1}^{-} \mathrm{r}_{\mathrm{F} 2}^{+} \mathrm{m}_{\mathrm{F} 2}^{+}$. If Haemophilus influenzae $\mathrm{R} f$ wild-type like strain $\mathrm{R} a$ possess two independent host-specificity systems, whereas mutant Rf IOr has only one, then phage HPICI carrying one type of modification grown in a strain possessing the second host-specificity system should yield among the progeny a few phage particles carrying both modifications HPI $c$ I . FI,F2 (Kellenberger, Symonds \& Arber, I966; Piekarowicz \& Glover, 1972). These particles originating from infection with HPIcI.FI should, and did, plaque equally well on strain $\mathrm{R} f$ and $\mathrm{R} f$ Ior (Table 8 ).

\section{Transfer of the host specificity systems of Haemophilus influenzae $\mathbf{R} f$ to $H$. influenzae strain $\mathrm{R} d$}

If the analysis of the host-specificity phenotypes of restriction-deficient mutants of $\mathrm{R} f$ demonstrating the existence of two independent host-specificity types in this strain is correct, then it should be possible to separate them genetically by transformation. Since Haemophilus influenzae $\mathrm{R} d$ is the most readily transformable strain, the Rd44I mutant $\mathrm{r}_{\mathrm{D}}^{-} \mathrm{m}_{\mathrm{D}}^{+}$(Glover \& Piekarowicz, 1972) lysogenic for HPI $c$ I phage was used as a recipient in these experiments. Integration of $H$. influenzae $\mathrm{R} f \mathrm{DNA}$ into the genome of $H$. influenzae $\mathrm{R} d$ is as efficient as for $H$. influenzae Rd DNA (unpublished observations). Strain Rd44I was transformed with a mixture of $\mathrm{R} f$ nov- $r$ and $\mathrm{R} f$ wild-type DNA. Novobiocin-resistant transformants were isolated and screened for $\mathrm{R} f$ host specificity. This selection procedure was based on the assumption that cells possessing $\mathrm{R} f$ host specificity should release phage able to plaque on either $\mathrm{R} f 232$ or $\mathrm{R} f \mathrm{IOI}$ indicator strains. However, in practice the transformed cells released so many phage particles that $\mathrm{R} f \mathrm{IOI} \mathrm{FI}^{+}$was not an effective indicator strain.

Among several thousands of novobiocin-resistant transformants of $\mathrm{R} d_{44} \mathrm{I}$ ( $\mathrm{HPI} c \mathrm{I}$ ) one was isolated with released phage $\mathrm{HPI} c \mathrm{I}$ which plaqued equally well on $\mathrm{R} d 44 \mathrm{I}$ and $\mathrm{R} f 232$ indicator bacteria. The properties of phage HPI $c$ I released by this particular transformant $\mathrm{R} d 44 \mathrm{I}$-TFI (shown in Table 9) indicate that Rd44I-TFI possesses two host-specificity systems, one specific for $\mathrm{R} d$ and the other specific for one of the systems present in Haemophilus influenzae $\mathrm{R} f$, the $\mathrm{FI}$ system. This experiment thus confirms the results of genetical analysis of restriction-deficient mutants of $H$. influenzae $\mathrm{R} f$ and demonstrates the existence of two independent host-specificity types in this strain. In addition it can be argued that the $h s$ loci 
Table 10. Restriction-deficient mutants of Haemophilus influenzae $\mathrm{R} b$.

\begin{tabular}{|c|c|c|c|c|}
\hline \multirow[b]{2}{*}{ Expt no. } & \multirow[b]{2}{*}{ Mutant no. } & \multirow{2}{*}{$\begin{array}{l}\text { Restriction } \\
\text { e.o.p. of HPIcI. } \text { O* }^{*} \\
\text { on mutant }\end{array}$} & \multicolumn{2}{|c|}{$\begin{array}{l}\text { Modification } \\
\text { e.o.p. of progeny phage } \\
\text { HPICI mutant on: }\end{array}$} \\
\hline & & & $\mathrm{R} b$ & Mutant \\
\hline I & $\begin{array}{l}\text { I } 88 \\
\text { II } 6\end{array}$ & $\begin{array}{l}1.8 \times 10^{-1} \\
5.0 \times 10^{-3}\end{array}$ & $\begin{array}{l}1 \cdot 0 \\
1.0\end{array}$ & $\begin{array}{l}I \cdot 0 \\
1 \cdot 0\end{array}$ \\
\hline II & $\begin{array}{l}218 \\
220 \\
234\end{array}$ & $\begin{array}{l}5.8 \times 10^{-1} \\
1.0 \\
5.0 \times 10^{-1}\end{array}$ & $\begin{array}{l}1 \cdot 0 \\
1 \cdot 0 \\
1 \cdot 0\end{array}$ & $\begin{array}{l}I \cdot 0 \\
I \cdot 0 \\
I \cdot 0\end{array}$ \\
\hline III & None & - & - & - \\
\hline IV & $\begin{array}{l}435 \\
437\end{array}$ & $\begin{array}{l}1.3 \times 10^{-1} \\
1 \cdot 0\end{array}$ & $\begin{array}{c}1.0 \\
3.4 \times 10^{-4}\end{array}$ & $\begin{array}{l}I \cdot 0 \\
I \cdot O\end{array}$ \\
\hline
\end{tabular}

The mutants were isolated after NTG treatment as described in Methods.

Expts I and II: NTG $300 \mu \mathrm{g} / \mathrm{ml}$, treatment for $15 \mathrm{~min}$ at $37^{\circ} \mathrm{C}$, $0.01 \%$ survival.

Expts III and IV: NTG $400 \mu \mathrm{g} / \mathrm{ml}$, treatment for $20 \mathrm{~min}$ at $37^{\circ} \mathrm{C}, 0.00 \mathrm{I} \%$ survival.

* HPIcI.O was phage grown on H. influenzae $\mathrm{R} d 30$ (Glover \& Piekarowicz, 1972).

Table II. Efficiency of plating on restriction-deficient mutants of Haemophilus influenzae $\mathrm{R} b$ of phage $H P \mathrm{I}$ c I previously grown on the mutants

\begin{tabular}{|c|c|c|c|c|c|c|c|c|c|}
\hline $\begin{array}{l}\text { Previous } \\
\text { host for }\end{array}$ & & & & & Strain & & & & \\
\hline HPIcI & $\mathrm{R} d 30$ & $\mathrm{R} b$ & $\mathrm{R} b \mathbf{I} 88$ & $\mathrm{R} b 116$ & $\mathrm{R} b 2 \mathrm{I} 8$ & $\mathrm{R} b 220$ & $\mathrm{R} b 234$ & $\mathrm{R} b 435$ & R $b 437$ \\
\hline $\mathrm{R} d 30$ & $I \cdot O$ & $\mathrm{I} \cdot 7 \times 10^{-4}$ & $\mathrm{I} \cdot 8 \times 10^{-1}$ & $5 \times 10^{-3}$ & $5^{.8} \times 10^{-1}$ & $1 \cdot 0$ & $5 \times 10^{-1}$ & $1 \cdot 3 \times 10^{-1}$ & $I \cdot O$ \\
\hline $\mathrm{R} b$ & $1 \cdot 0$ & $I \cdot O$ & $I \cdot O$ & $1 \cdot 0$ & $\mathrm{I} \cdot O$ & 1.0 & $1 \cdot 0$ & $I \cdot O$ & $I \cdot O$ \\
\hline $\mathbf{R} b \mathbf{I} 88$ & $I \cdot 0$ & $I \cdot O$ & $I \cdot O$ & $I \cdot O$ & $I \cdot O$ & $I \cdot 0$ & $I \cdot O$ & $1 \cdot 0$ & $1 \cdot 0$ \\
\hline $\mathrm{R} b \mathrm{I} 16$ & $I \cdot O$ & $I \cdot O$ & $1 \cdot 0$ & $I \cdot O$ & $I \cdot O$ & $I \cdot O$ & $I \cdot O$ & $1 \cdot 0$ & $I \cdot O$ \\
\hline $\mathrm{R} b 2 \mathrm{I} 8$ & $1 \cdot 0$ & $1 \cdot 0$ & $I \cdot O$ & $I \cdot O$ & $I \cdot O$ & $I \cdot 0$ & $I \cdot O$ & $I \cdot 0$ & $I \cdot O$ \\
\hline $\mathrm{R} b 220$ & $I \cdot O$ & $I \cdot O$ & $1 \cdot 0$ & $I \cdot O$ & $1 \cdot 0$ & $1 \cdot 0$ & $1 \cdot 0$ & $1 \cdot 0$ & $I \cdot O$ \\
\hline $\mathrm{R} b 234$ & $I \cdot 0$ & $I \cdot O$ & $\mathbf{I} \cdot 0$ & $I \cdot O$ & $I \cdot O$ & $I \cdot O$ & $I \cdot O$ & $I \cdot O$ & $I \cdot O$ \\
\hline $\mathrm{R} b 435$ & 1.0 & $I \cdot O$ & $I \cdot 0$ & $I \cdot O$ & $I \cdot O$ & $I \cdot 0$ & $I \cdot O$ & $1 \cdot 0$ & $I \cdot O$ \\
\hline $\mathrm{R} b 437$ & $1 \cdot 0$ & $3.4 \times 10^{-4}$ & $6.2 \times 10^{-2}$ & $6.5 \times 10^{-3}$ & $I \cdot O$ & $1 \cdot 0$ & $1 \cdot 0$ & $8 \times 10^{-2}$ & $I \cdot O$ \\
\hline $\begin{array}{l}\text { notype } \\
\text { duced }\end{array}$ & & $\mathrm{r}^{+} \mathrm{m}^{+}$ & $\mathrm{r}^{ \pm} \mathrm{m}^{+}$ & $\mathrm{r}^{ \pm} \mathrm{m}^{+}$ & $\mathrm{r}^{-} \mathrm{m}^{+}$ & $\mathrm{r}^{-} \mathrm{m}^{+}$ & $\mathrm{r}^{-} \mathrm{m}^{+}$ & $\mathrm{r}^{ \pm} \mathrm{m}^{+}$ & $\mathbf{r}^{-} \mathrm{m}^{-}$ \\
\hline
\end{tabular}

of the D and FI systems are not allelic since they are both present in the transformant Rd44I-TFI.

\section{Isolation of restriction-deficient mutants of Haemophilus influenzae $\mathrm{R} b$}

Piekarowicz \& Glover (1972) showed that unmodified phage HPIcI.O is restricted by Haemophilus influenzae $\mathrm{R} b$ with e.o.p. about $1 \mathrm{O}^{-4}$. In the light of the results of genetical analysis of host specificity in $H$. influenzae $\mathrm{R} d$ (Glover \& Piekarowicz, 1972), R $a$ (Piekarowicz \& Glover, 1972) and in $\mathrm{R} f$ as shown above, an e.o.p. of $10^{-4}$ for HPI $c \mathrm{I}$.O on strain $\mathrm{R} b$ indicates that this strain may have only one host-specificity system. To test this possibility restriction-deficient mutants of $H$. influenzae $\mathrm{R} b$ were isolated and their phenotypes tested.

The restriction-deficient mutants of Haemophilus influenzae $\mathrm{R} b$ were isolated following NTG mutagenesis (Table Io). Among several restriction-deficient mutants only two were completely permissive for HPI $c$ I.O. However, they differ in modification. One of them, $\mathbf{R} b 437$, is completely modification-deficient and the other, $\mathbf{R} b 220$, has the same modification 
properties as the parental strain $\mathbf{R} b$. The phenotypes of these mutants are therefore $\mathrm{r}_{\mathbf{B}}^{-} \mathrm{m}_{\mathbf{B}}^{-}$ and $r_{B}^{-} m_{B}^{+}$. Mutants with the phenotype $r_{B}^{ \pm} m_{B}^{+}$were also isolated.

The results of the chequer-board experiment presented in Table II demonstrate that Haemophilus influenzae $\mathrm{R} b$ possesses only one restriction and modification system since none of the mutants compared pair-wise show mutually exclusive restriction and modification properties.

\section{DISCUSSION}

Strain Haemophilus influenzae Rf carries two DNA host-specificity systems which were designated Fr and F2. The host specificity phenotype of $H$. influenzae $\mathrm{R} f$ is therefore $\mathbf{r}_{\mathrm{F} 1}^{+} \mathrm{m}_{\mathrm{F} 1}^{+} \mathbf{r}_{\mathrm{F} 2}^{+} \mathrm{m}_{\mathrm{F} 2}^{+}$. Results of the following experiments argue for their independence. Analysis of the restriction-deficient mutants of $\mathrm{R} f$ revealed strains possessing only one host-specificity type. Most of the predictable phenotypes for mutants of these two systems were obtained after mutagenesis. All of the mutants isolated after a single mutagenic treatment was affected in a single host-specificity system, i.e. either FI or F2 but never in both. Double mutants affected in both systems were only obtained after mutagenic treatment of previously isolated mutants defective in either $\mathrm{F}_{1}$ or $\mathrm{F}_{2}$. The two host-specificity systems of $\mathrm{R} f$ were separated by transformation. Using donor DNA from $H$. influenzae $\mathrm{R} f$ and $H$. influenzae $\mathrm{R} d$ as a recipient, a transformant possessing the recipient $\mathrm{D}$ and the donor FI systems was obtained. The donor F2 system was not inherited by this transformant.

The efficiency of plating of phage HPIcI.O on Haemophilus influenzae $\mathrm{R} f$ is reduced to an extremely low level, $\mathrm{I} \times \mathrm{IO}^{-9}$, as a result of the activity of these two systems, which are roughly additive. The FI system reduces the e.o.p. to $\mathrm{I} \times \mathrm{IO}^{-6}$ and $\mathrm{F}_{2}$ reduces the e.o.p. to $\mathrm{I} \times \mathrm{IO}^{-3}$. The level of restriction expressed by the FI system is one of the highest for a single hostspecificity system known so far. Within limits, the restriction coefficient for a given phage by a given system is a measure of the number of sites present on the phage DNA (Franklin \& Dove, I969; Murray, Manduca de Ritis \& Foster, I973). Phage $f_{1}$.O for example, which has two sites for the B system, has an e.o.p. $\mathrm{IO}^{-4}$ on Escherichia coli $\mathrm{B}$ (Boon \& Zinder, 197I) but mutants which have lost either of two $\mathrm{sB}$ sites are restricted with an e.o.p. $10^{-2}$ (Lyons \& Zinder, 1972). Thus, the e.o.p. of $10^{-6}$ observed for phage HPI $c$ I in the Fr system may reflect the presence of several sensitive sites on its DNA. On the other hand, this high level of restriction may mean that FI restriction endonuclease is present in larger amounts than other endonucleases, or it is more efficient, or it is not subject to the physiological influences which frequently affect the fraction of permissive cells in a population.

Genetical analysis of the host-specificity types in Haemophilus influenzae strains has revealed that the e.o.p. of unmodified $\mathrm{HPI}, \mathrm{HPI} c \mathrm{I}$ and $\mathrm{S} 2$ phages is related to the number of host-specificity types carried by these strains. Thus, the e.o.p. of phage HPIcI.O on $H$. influenzae $\mathrm{R} a$ is reduced to $5 \times 10^{-6}$ as a result of the activity of two systems $\mathrm{AI}$ and $\mathrm{A2}$ (Piekarowicz \& Glover, I972), the e.o.p. of phage HPIcI.O on H. influenzae $\mathrm{Rd}$ is $\mathrm{IO}^{-3}$ (Glover \& Piekarowicz, 1972) and on $\mathrm{R} b$ is about $\mathrm{IO}^{-4}$, and both these strains have only one system of host specificity. The extremely low e.o.p. on $\mathrm{R} f$ and $\mathrm{R} e$ strains is due to two independent systems present in these strains.

We do not know whether these two systems are determined by chromosomal or plasmid genes.

The phenotypes of restriction-deficient mutants $F_{1}$ and $F_{2}$ fall into two classes in respect of modification; those which are modification-deficient and those which are modificationproficient. These results are compatible with the three-gene model of restriction and modification (Arber \& Linn, 1969; Glover, 1970; Boyer, 1971). According to this model, $\mathrm{r}^{-} \mathrm{m}^{+}$ 
mutants arise as a result of mutations in a gene $h s r$ which is necessary for restriction, and $\mathbf{r}^{-} \mathrm{m}^{-}$mutants are due to mutations in a gene hss which is necessary for restriction and modification. Mutations in $h s m$ also affect restriction and modification (Hubacek \& Glover, 1970). The fact that we isolated $\mathrm{r}^{-} \mathrm{m}^{-}$and $\mathrm{r}^{-} \mathrm{m}^{+}$one-step mutants for both the $\mathrm{F}_{1}$ and $\mathrm{F}_{2}$ systems could be taken to mean that these host specificities are each controlled by a set of three genes. Thus, it would appear that all the known systems of restriction and modifications in Haemophilus influenzae characterized genetically can be classified as type I according to the classification of host-specificity systems by Boyer (197I). However, it cannot be ruled out that in these Haemophilus systems only two genes are involved, one of them essential for modification but both of them essential for restriction. The recent isolation of an endonuclease from $\mathrm{R} d$ by Gromkova et al. (1973) which is S-adenosyl-methionine-dependent would indicate that the $\mathbf{r}_{\mathbf{D}}^{+}$system is type $\mathrm{I}$.

It is well established that the genes controlling $\mathrm{K}, \mathrm{B}$ and $\mathrm{A}$ restriction and modification in Escherichia coli are allelic (Boyer, 1964; Colson, Glover, Symonds \& Stacey, 1965; Lederberg, 1966; Wood, 1966; Arber \& Wauters-Willems, 1970). The close relatedness of these genes is also reflected in the functional complementation found for some of their products (Glover, 1968; Boyer \& Roulland-Dussoix, 1969; Arber \& Linn, 1969). No such analysis can be carried out for Haemophilus influenzae host specificities; nevertheless it seems that at least some of them are not allelic. The fact that we were able to isolate a strain carrying both the D and FI systems shows that these two systems are not allelic. These two systems differ also in expression. It is known that the D system is very unstable (Glover \& Piekarowicz, I972) in contrast to any other $H$. influenzae host-specificity system (Piekarowicz \& Glover, 1972; Piekarowicz \& Kalinowska, 1973). Moreover, in the strain carrying both the $\mathrm{D}$ and $\mathrm{F}_{\mathrm{I}}$ systems $\mathrm{D}$ is still unstable while $\mathrm{F}_{\mathrm{I}}$ is stable (unpublished observations).

The fact that $\mathrm{r}^{-} \mathrm{m}^{+}$and $\mathrm{r}^{-} \mathrm{m}^{-}$mutants were obtained for each host-specificity system in strains which were wild type for the second host-specificity system makes it unlikely that the two systems of Haemophilus influenzae $\mathrm{R} f$ are functionally related and cannot like Escherichia coli $\mathrm{K}$ and $\mathrm{B}$ types complement one another by exchange of subunits. The genetic analysis of H. influenzae has inherent limitations which do not allow complementation tests to be carried out, so that it is not possible to establish directly the relationship between the different host-specificity systems present in these bacteria.

This work was supported in part by the Polish Academy of Sciences within Project No. 09.3.I. We should like to thank Sue Johnson for her excellent technical assistance.

\section{REFERENCES}

Adams, M. H. (1959). Bacteriophages. New York: Interscience Publishers.

Arber, W. \& Linn, S. (1969). DNA modification and restriction. Annual Review of Biochemistry 38, 467-500.

Arber, W. \& WAUTERS-WILlems, D. (1970). Host specificity of DNA produced by Escherichia coli. XII. The two restriction and modification systems of strain I $^{\mathrm{T}}$. Molecular and General Genetics 108, $203-217$.

Bendler, J. W. \& Goodgal, S. H. (1968). Prophage S2 mutants in Haemophilus influenzae: a technique for their production and isolation. Science, New York 162, 464-465.

Bigger, C. H., Murray, K. \& Murray, N. E. (I973). Recognition sequence of a restriction enzyme. Nature New Biology 244, 2-IO.

Boon, T. \& ZINDER, N. D. (197I). Genotypes produced by individual recombination events involving bacteriophage fi. Journal of Molecular Biology 58, 133-15I.

BOYER, H. W. (1964). Genetic control of restriction and modification in Escherichia coli. Journal of Bacterio$\log y 88, \mathrm{I} 652-\mathrm{I} 660$.

BOYER, H. W. (197I). DNA restriction and modification mechanisms in bacteria. Annual Review of Microbiology 25, I 53-176. 
BOYER, H. W. \& RoullaNd-Dussoix, D. (1969). A complementation analysis of the restriction and modification of DNA in Escherichia coli. Journal of Molecular Biology 4I, 459-472.

Brockes, J. P., Brown, P. R. \& MuRray, K. (I972). The deoxyribonucleic acid modification enzyme of bacteriophage PI. Biochemical Journal 127, I-IO.

Colson, C., Glover, S. W., Symonds, N. \& Stacey, K. A. (I965). The location of the genes for hostcontrolled modification and restriction in Escherichia coli KI2. Genetics 52, I043-1050.

Franklin, N. C. \& Dove, W. (1969). Genetic evidence for restriction targets in the DNA of phages $\lambda$ and $\phi 80$. Genetical Research $\mathbf{1 4}, 15 \mathrm{I}-157$.

GLOVER, S. W. (1968). Host specificity in $\mathrm{F}^{\prime}$ heterogenotes of Escherichia coli. Journal of General Microbiology 53, i-ii.

GLOVER, S. W. (1970). Functional analysis of host-specificity mutants in Escherichia coli. Genetical Research I5, 237-250.

Glover, S. W. \& PIeKarowicz, A. (1972). Host specificity of DNA in Haemophilus influenzae: restriction and modification in strain Rd. Biochemical and Biophysical Research Communications 46, 1610-1618.

Goodgal, S. H. \& Herriott, R. M. (1961). Studies on transformation of Haemophilus influenzae. I. Competence. Journal of General Physiology 44, I20I-I227.

Gromkova, R., BendleR, J. \& Goodgal, S. H. (1973). A study of restriction and modification of bacteriophage $\mathrm{S}_{2}$ in Haemophilus influenzae. Journal of Bacteriology II $_{4}$, I $15 \mathrm{I}-\mathrm{I} 157$.

Gromkova, R. \& Goodgal, S. H. (1972). Action of Haemophilus endodeoxyribonuclease on biologically active deoxyribonucleic acid. Journal of Bacteriology 109, 987-992.

HARM, W. \& RUPERT, C. S. (1963). Infection of transformable cells of Haemophilus influenzae by bacteriophage and bacteriophage DNA. Zeitschrift für Vererbungslehre 94, 336-348.

Hattman, S., Gold, E. \& PlotniK, A. (1972). Methylation of cytosine residues in DNA controlled by a drug resistance factor. Proceedings of the National Academy of Sciences of the United States of America 69, $187-190$.

Hedgpeth, J., Goodman, H. M. \& Boyer, H. W. (1972). DNA nucleotide sequence restricted by the RI endonuclease. Proceedings of the National Academy of Sciences of the United States of America 69, 3448-3452.

HubaceK, J. \& Glover, S. W. (I970). Complementation analysis of temperature-sensitive host specificity mutations in Escherichia coli. Journal of Molecular Biology 50, II I-I 27.

Kellenberger, G., Symonds, N. \& ARber, W. (1966). Host specificity of DNA produced by Escherichia coli. VIII. Its acquisition by phage $\lambda$ and its persistance through consecutive growth cycles. Zeitschrift für Vererbungslehre 98, 247-256.

Kelly, T. J. \& Smith, H. O. (1970). A restriction enzyme from Haemophilus influenzae. II. Base sequence of the recognition site. Journal of Molecular Biology 51, 393-409.

LEDERBERG, S. (1966). Genetics of host-controlled restriction and modification of deoxyribonucleic acid in Escherichia coli. Journal of Bacteriology 91, 1029-1036.

LINN, S. \& ARBER, W. (I968). Host specificity of DNA produced by Escherichia coli. X. In vitro restriction of phage fd replicative form. Proceedings of the National Academy of Sciences of the United States of America 59, I300-1 306.

LYONS, L. B. \& ZINDER, N. D. (1972). The genetic map of the filamentous bacteriophage fr. Virology 49, $45-60$.

MARMUR, J. (1961). A procedure for the isolation of deoxyribonucleic acid from micro-organisms. Journal of Molecular Biology 3, 208-218.

Meselson, M. \& YuAN, R. (I968). DNA restriction enzyme from E. coli. Nature, London 217, I I IO-I II4.

Michalka, J. \& Goodgal, S. H. (1969). Genetic and physical map of the chromosome of Haemophilus influenzae. Journal of Molecular Biology 45, 407-42I.

Murray, N. E., ManduCa de Ritis, P. \& Foster, L. A. (I973). DNA targets for the Escherichia coli $\mathrm{K}$ restriction system analysed genetically in recombinants between phages Phi8o and lambda. Molecular and General Genetics 120, 26I-281.

Piekarowicz, A. \& Glover, S. W. (1972). Host specificity of DNA in Haemophilus influenzae: the two restriction and modification systems in strain Ra. Molecular and General Genetics II6, II-25.

Piekarowicz, A. \& KalinowsKa, J. (1974). Host specificity of DNA in Haemophilus influenzae: similarity between host-specificity types of Haemophilus influenzae $\mathrm{R} e$ and $\mathrm{R} f$. Journal of General Microbiology 8r, 405-4II.

ROullaNd-Dussoix, D. \& BOYER, H. W. (1969). The Escherichia coli в restriction endonuclease. Biochimica et biophysica acta r95, 219-229. 
Sмiтh, H. O. \& WiLcox, K. W. (1970). A restriction enzyme from Haemophilus influenzae. I. Purification and general properties. Journal of Molecular Biology 5I, 379-39I.

Smith, J. D., ARber, W. \& KühnLeIN, U. (1972). Host specificity of DNA produced by E. coli. XIV. The role of nucleotide methylation in in vivo B-specific modification. Journal of Molecular Biology 63, I-8.

SPENCER, H. T. \& HERRIOTT, R. M. (1965). Development of competence of Haemophilus influenzae. Journal of Bacteriology 9o, 91 I-920.

Woon, W. B. (1966). Host specificity of DNA produced by Escherichia coli. Bacterial mutations affecting the restriction and modification of DNA. Journal of Molecular Biology 16, I I8-I 33. 